\title{
Hubungan Pekerjaan Ibu, Jenis Kelamin, dan Pemberian Asi Eklusif Terhadap Kejadian Stunting Pada Balita 6-59 Bulan di Bangka Selatan
}

\section{The Relationship of Maternal Employment, Gender, and ASI Eklusif with Incident of Stunting inToddler Aged 6-59 Months in South Bangka}

\author{
Riza Savita ${ }^{1 *}$, dan Fitra Amelia ${ }^{2}$ \\ STIKES Citra Delima Bangka Belitung, Indonesia ${ }^{1,2}$ \\ *Email Korespondensi : rizasavita55@gmail.com
}

\begin{abstract}
Abstrak
Latar belakang: Stunting merupakan gangguan pertumbuhan linier dan apabila terjadi pada masa golden period perkembangan otak (0-3 tahun), maka berakibat pada perkembangan otak yang tidak baik. Hal tersebut di masa yang akan datang dapat berakibat pada penurunan kemampuan intelektual dan produktivitas, peningkatan risiko penyakit degeneratif dan kelahiran bayi dengan berat lahir rendah atau premature.

Tujuan: Mengetahui hubungan antara Pekerjaan Ibu, Jenis Kelamin, dan Pemberian ASI Eklusif terhadap kejadian Stunting.

Metode: penelitian ini adalah menggunakan desain Case Control dengan jumlah besaran sample dalam penelitian ini adalah160 responden. Analisa data yang digunakan dalam penelitian ini adalah Analisis Univariat dan Analisis Bivariat.

Hasil: membuktikan bahwa ada hubungan antara Pekerjaan ibup-value $(0,000)$ danASI Eklusifp-value $(0,004)$ dengan Kejadian Stunting pada Balita 6-59 Bulan di Kabupaten Bangka Selatan serta tidak ada hubungan antara jenis kelamin dengan kejadian Stunting pada Balita 6-59 Bulan di Kabupaten Bangka Selatan.

Kesimpulan: Pada penelitian ini pekerjaan ibu dan ASI eksklusif berhubungan dengan kejadian stunting. Dengan ini ibu dapat memberikan ASI eksklusif dan mengatur jam kerjanya sebaik mungkin untuk merawat bayinya dan berupaya untuk membawa anaknya untuk ke posyandu atau pelayanan kesehatan lainnya agar pertumbuhan bayi terkontrol sehingga dapat mencegah stunting.
\end{abstract}

Kata kunci:ASI Eklusif, Balita, Jenis Kelamin, Pekerjaan Ibu, Stunting.

\begin{abstract}
Background: Stunting is a linear growth disorder and if it occurs in the golden periodof brain development (0-3 years), it may results in poor brain development. This in the future can result in decreased intellectual abilities and productivity, increased risk of degenerative diseases and the birth of babies with low birth weight or premature.

Objective: to know the relationship between Mother's Work, Gender, and Exclusive Breastfeeding with Stunting.

Method: This study used a case control design with a total sample size of 160 respondents. The datathen analyzed withunivariate and bivariate analyses.

Result: The results of this study prove that there was a relationship between maternal employment p-value $(0,000)$ and exclusive breastfeeding p-value (0.004) with the incident of stunting in infants aged 6-59 months in South Bangka Regency and there was no relationship between gender with the incidence of stunting in infants aged 6-59 Months in South Bangka Regency.

Conclusion: In this study the work of mothers and exclusive breastfeeding were related to the incidence of stunting. Mothers who can provide exclusive breastfeeding and arrange her working hours can provide care for their baby, do scheduled visit to Posyandu or other health services to monitor the growth of their baby and prevent the risk of stunting.
\end{abstract}

Keywords: Exclusive Breastfeeding, Gender, Maternal Employment, Stunting, Toddler 


\section{PENDAHULUAN}

Hasil Riset Kesehatan Dasar tahun 2013, menyatakan bahwa prevalensi kejadian balitastunting di Indonesia mengalami fluktuatif pada tahun 2007, tahun 2010 dan tahun 2013. Data tersebut menyatakan bahwa persentase kejadian balita stunting pada tahun 2007 sebesar $(36,8 \%)$, pada tahun 2010 terjadi penurunan kasus balita stunting sebesar (35,6\%) dan pada tahun 2013 mengalami peningkatan sebesar $(37,2 \%)$ kasus balita stunting. ${ }^{1}$

Berdasarkan hasil Pemantauan Status Gizi (PSG) tahun 2016 menurut Provinsi prevalensistunting tertinggi terdapat di Provinsi Nusa Tenggara Timur sebesar $(38,7 \%)$ kasus balitastunting, Sulawesi Selatan sebesar $(35,6 \%)$ kasus balita stunting, Kalimantan Barat sebesar $(34,9 \%)$ kasus balita stunting dan Kepulauan Bangka Belitung menduduki peringkat ke 25 dari 34 Provinsi yang ada di Indonesia dengan prevalensi stunting sebesar $(21,9 \%)$ kasus balitastunting. ${ }^{2}$

Kasus balita stunting di Provinsi Kepulauan Bangka Belitung dari tahun 2015 hingga tahun 2017 terjadi peningkatan prevalensi stunting pada balita usia 0-59 bulan menurut Indeks tinggi badan menurut umur (TB/U). Pada tahun 2017 prevalensi stunting tertinggi terdapat di Kabupaten Bangka Selatan sebesar (30,0\%), Kabupaten Belitung Timur sebesar (29,3\%), Kabupaten Bangka sebesar (27,7\%), Kabupaten Belitung sebesar (27,7\%), Kota Pangkalpinang sebesar (26,7\%), Kabupaten Bangka Tengah sebesar (25,6\%) dan terendah Kabupaten Bangka Barat sebesar (25,0\%). Persentase tersebut dengan pembagian kategori sangat pendek dan pendek. ${ }^{3}$

Stunting merupakan gangguan pertumbuhan linier dan apabila terjadi pada masa goldenperiod perkembangan otak (0-3 tahun), maka berakibat pada perkembangan otak yang tidak baik. Hal tersebut di masa yang akan datang dapat berakibat pada penurunan kemampuan intelektual dan produktivitas, peningkatan risiko penyakit degeneratif dan kelahiran bayi dengan berat lahir rendah atau premature. ${ }^{4}$

Menurut UNICEF pertumbuhan pada Balita dipengaruhi oleh faktor langsung diantaranya adalah asupan energi, asupan protein, BBLR, dan keadaan kesehatan seperti penyakit infeksi dan faktor tidak langsung meliputi pemberian ASI Eksklusif, jenis kelamin balita, tinggi badan ibu, tingkat pendidikan ibu dan status ekonomi. Upaya masyarakat dalam membantu menurunkan prevalensi stunting dapat dilakukan dengan cara melalu kunjungan anak ke posyandu tepat waktu. Sehingga pertumbuhan anak dapat terpantau dengan baik dan dapat mencegah stunting. ${ }^{5}$

Berdasarkan latar belakang yang telah diuraikan di atas, maka dapat dirumuskan masalahnya yaitu "Adakah Hubungan Pekerjaan Ibu, Jenis Kelamin, dan Pemberian ASI Eksklusif Terhadap Kejadian Stunting Pada Balita 6-59 Bulan di Kabupaten Bangka Selatan?

Tujuan penelitian ini adalah untuk mengetahui hubungan antara Pekerjaan Ibu, Jenis Kelamin, dan Pemberian ASI Eklusif terhadap kejadian Stunting pada balita 6-59 bulan di Kabupaten Bangka Selatan.

\section{METODE}

Penelitian ini merupakan penelitian observasional dengan desain case control yang dilaksankan di Kabupaten Bangka Selatan pada bulan April - Agustus tahun 2019. Jumlah besaran sample dalam penelitian ini adalah 80 balita kelompok kasus dan 80 balita kelompok kontrol yang berjumlah 160 responden. Variabel yang diteliti adalah Pekerjaan ibu, Jenis Kelamin Balita dan Pemberian Asi esklusif diperoleh dengan menggunakan metode wawancara menggunakan kuesioner.

Analisis dilakukan secara univariat dan bivariat. Analisis univariat untuk mengetahui distribusi masing-masing variabel, sedangkan Analisis bivariat adalah analisis yang dilakukan untuk menguji hubungan antara variabel bebas dan variabel terikat yaitu pekerjaan ibu, jenis kelamin balita, dan pemberian ASI eksklusif terhadap kejadian stunting.

\section{HASIL}

\section{Analisa Univariat}

Tujuan dari analisis ini adalah untuk menjelaskan atau mendskripsikan karakteristik masing-masing variabel yang diteliti, dimana analisis ini dilakukan terhadap tiap variabelpenelitian. Variabel 
independen (Pekerjaan Ibu, Jenis Kelamin Balita, dan ASI Eklusif) dan Variabel dependen (Kejadian Stunting) adalah. Hasil dari variabel-variabel tersebut dapat dilihat pada tabel berikut ini :

Tabel 1. Distribusi Respoden Berdasarkan Kejadian Stunting.

\begin{tabular}{|c|c|c|}
\hline Variabel & $\begin{array}{c}\text { Jumlah } \\
\text { (n) }\end{array}$ & $\begin{array}{c}\text { Persentase } \\
(\%)\end{array}$ \\
\hline Stunting (Kasus) & 80 & 50 \\
\hline Tidak Stunting (Kontrol) & 80 & 50 \\
\hline Jumlah & 160 & 100 \\
\hline
\end{tabular}

Pada tabel 1 menunjukan bahwa, responden yang mengalami Stunting (Kasus) sebanyak 80 orang (50\%) sama dengan responden yang tidak mengalami Stunting (Kontrol) sebanyak 80 orang (50\%), karena penelitian ini menggunakan perbandingan 1:1.

Tabel 2. Distribusi Respoden Berdasarkan Pekerjaan Ibu.

\begin{tabular}{|c|c|c|}
\hline Variabel & $\begin{array}{c}\text { Jumlah } \\
\text { (n) }\end{array}$ & $\begin{array}{c}\text { Persentase } \\
(\%)\end{array}$ \\
\hline \multicolumn{3}{|l|}{ Pengetahuan Ibu } \\
\hline Tidak Bekerja & 109 & 68,1 \\
\hline Bekerja & 51 & 31,9 \\
\hline Jumlah & 160 & 100 \\
\hline
\end{tabular}

Pada tabel 2 menunjukan bahwa, ibu yang tidak bekerja $(68,1 \%)$, lebih banyak dibandingkan dengan ibu yang bekerja $(31,9 \%)$.

Tabel 3. Distribusi Respoden Berdasarkan Jenis Kelamin Balita.

\begin{tabular}{|c|c|c|}
\hline Variabel & $\begin{array}{c}\text { Jumlah } \\
\text { (n) }\end{array}$ & $\begin{array}{c}\text { Persentase } \\
(\%)\end{array}$ \\
\hline \multicolumn{3}{|l|}{ Jenis Kelamin Balita } \\
\hline Laki-laki & 80 & 50 \\
\hline Perempuan & 80 & 50 \\
\hline Jumlah & 160 & 100 \\
\hline
\end{tabular}

Pada tabel 3 menunjukan bahwa, balita berjenis kelamin laki-laki (50\%), samadengan balita berjenis kelamin perempuan $(50 \%)$.

Tabel 4. Distribusi Respoden Berdasarkan Pemberian ASI Eklusif.

\begin{tabular}{lcc}
\hline \multicolumn{1}{c}{ Variabel } & $\begin{array}{c}\text { Jumlah } \\
(\mathbf{n})\end{array}$ & $\begin{array}{c}\text { Persentase } \\
(\boldsymbol{\%})\end{array}$ \\
\hline Pemberian ASI Eksklusif & & \\
Tidak Eksklusif & 81 & 50,6 \\
Eksklusif & 79 & 49,4 \\
Jumlah & 160 & 100 \\
\hline
\end{tabular}

Pada tabel 4 menunjukan bahwa ibu yang memberikan ASI tidak Eklusif sebanyak $(50,6 \%)$, lebih banyak dibandingkan dengan ibu yang memberikan ASI Eklusif $(49,4 \%)$. 
Analisa Bivariat

Tabel 5. Hubungan Antara Pekerjaan Ibu Dengan Kejadian Stunting Pada Balita 6-59 BulanDi Kabupaten Bangka Selatan.

\begin{tabular}{|c|c|c|c|c|c|c|c|c|}
\hline \multirow{3}{*}{ Pekerjaan Ibu } & \multicolumn{4}{|c|}{ Kejadian Stunting } & \multirow{2}{*}{\multicolumn{2}{|c|}{ Total }} & \multirow{3}{*}{$p$-value } & \multirow{3}{*}{$\begin{array}{c}\text { OR } \\
(95 \% \mathrm{CI})\end{array}$} \\
\hline & \multicolumn{2}{|c|}{ Stunting (kasus) } & \multicolumn{2}{|c|}{$\begin{array}{l}\text { Tidak Stunting } \\
\text { (Kontrol) }\end{array}$} & & & & \\
\hline & $\mathrm{n}$ & $\%$ & $\mathrm{n}$ & $\%$ & $\mathrm{~N}$ & $\%$ & & \\
\hline Tidak Bekerja & 68 & $62,4 \%$ & 41 & $37,6 \%$ & 109 & $100 \%$ & \multirow{2}{*}{0,000} & \multirow{2}{*}{$\begin{array}{r}5,390 \\
(2,536- \\
11,459)\end{array}$} \\
\hline Bekerja & 12 & $23,5 \%$ & 39 & $76,5 \%$ & 51 & $100 \%$ & & \\
\hline
\end{tabular}

Berdasarkan tabel 5 dijelaskan bahwa ibu yang tidak bekerja lebih banyak ditemukan pada responden yangstunting (kasus) sebanyak 68 orang dibandingkan responden yang mengalami tidak stunting (kontrol), sedangkan ibu yang bekerja lebih banyak ditemukan pada responden yang tidak stunting (kontrol) sebanyak 39 orang dibandingkan responden yang mengalami stunting (kasus).

Hasil Pengujian ini secara statistik diperoleh $p$-value $=0,000<0,05$, hasil ini dapat disimpulkan ada hubungan yang signifikan antara pekerjaan ibu dengan kejadian stunting. Analisa lebih lanjut diperoleh nilai $\mathrm{OR}=5,390(95 \% \mathrm{CI}: 2,536-11,459)$, sehingga dapat disimpulkan ibu yang tidak bekerja memiliki kecenderungan 5 kali anak akan mengalami stunting dibandingkan dengan ibu yang bekerja

Tabel 6. Hubungan Antara Jenis Kelamin Balita Dengan Kejadian Stunting Pada Balita 6-59 Bulan Di Kabupaten Bangka Selatan.

\begin{tabular}{|c|c|c|c|c|c|c|c|c|}
\hline \multirow{3}{*}{ Jenis Kelamin Balita } & \multicolumn{4}{|c|}{ Kejadian Stunting } & \multirow{2}{*}{\multicolumn{2}{|c|}{ Total }} & \multirow{3}{*}{$p$-value } & \multirow{3}{*}{$\begin{array}{c}\text { OR } \\
(95 \% \mathrm{CI})\end{array}$} \\
\hline & \multicolumn{2}{|c|}{ Stunting (kasus) } & \multicolumn{2}{|c|}{$\begin{array}{l}\text { Tidak Stunting } \\
\text { (Kontrol) }\end{array}$} & & & & \\
\hline & $\mathrm{N}$ & $\%$ & $\mathrm{n}$ & $\%$ & $\mathrm{~N}$ & $\%$ & & \\
\hline Laki-laki & 39 & $48,8 \%$ & 41 & $51,3 \%$ & 80 & $100 \%$ & \multirow{2}{*}{0,874} & 0,905 \\
\hline Perempuan & 41 & $51,3 \%$ & 39 & $48,8 \%$ & 80 & $100 \%$ & & $(0,487-1,682)$ \\
\hline
\end{tabular}

Pada tabel 6 dijelaskan bahwa, balita yang berjenis kelamin laki-laki lebih banyak ditemukan pada responden yang tidak stunting (kontrol) sebanyak 41 orang dibandingkan dengan responden yang mengalami stunting (kasus), sedangkan balita yang berjenis kelamin perempuan lebih banyak ditemukan pada responden yang stunting (kasus) sebanyak 41 orang dibandingkan dengan responden yang mengalami tidakstunting (kontrol).

Hasil Pengujian ini secara statistik diperoleh $p$-value $=0,874>0,05$, hasil ini dapat disimpulkan tidak ada hubungan yang signifikan antara jenis kelamin balita dengan kejadian stunting. Analisa lebih lanjut diperoleh nilai OR $=0,905$ (95\%CI: 0,487 - 1,682), sehingga dapat disimpulkan balita berjenis kelamin laki-laki memiliki kecederungan 1 kali akan mengalami stunting dibandingkan dengan balita berjenis kelamin perempuan. 
Tabel 7. Hubungan Antara Pemberian ASI Eklusif Dengan Kejadian Stunting Pada Balita 6-59 Bulan Di Kabupaten Bangka Selatan.

\begin{tabular}{|c|c|c|c|c|c|c|c|c|}
\hline \multirow{3}{*}{ ASI Eksklusif } & \multicolumn{4}{|c|}{ Kejadian Stunting } & \multirow{2}{*}{\multicolumn{2}{|c|}{ Total }} & \multirow{3}{*}{$p$-value } & \multirow{3}{*}{$\begin{array}{c}\text { OR } \\
(95 \% \mathrm{CI})\end{array}$} \\
\hline & \multicolumn{2}{|c|}{ Stunting (kasus) } & \multicolumn{2}{|c|}{$\begin{array}{l}\text { Tidak Stunting } \\
\text { (Kontrol) }\end{array}$} & & & & \\
\hline & $\mathrm{n}$ & $\%$ & $\mathrm{n}$ & $\%$ & $\mathrm{~N}$ & $\%$ & & \\
\hline Tidak eksklusif & 50 & $61,7 \%$ & 31 & $38,3 \%$ & 81 & $100 \%$ & & 2.634 \\
\hline Eksklusif & 30 & $38 \%$ & 49 & $62 \%$ & 79 & $100 \%$ & & $(1$ \\
\hline
\end{tabular}

Pada tabel 7 dijelaskan bahwa, ibu yang memberikan ASI tidak eklusif lebih banyak terdapat pada responden yang mengalami stunting (kasus) sebanyak 50 orang dibandingkan dengan responden yang tidak mengalami stunting (kontrol), sedangkan ibu yang memberikan ASI eklusif lebih banyak terdapat pada responden yang tidak stunting (kontrol) sebanyak 49 orang dibandingkan dengan responden yang mengalami stunting (kasus).

Hasil Pengujian ini secara statistik diperoleh $p$-value $=0,004<0,05$, hasil ini dapat disimpulkan ada hubungan yang signifikan antara balita yang mendapatkan ASI Eksklusif dengan kejadian stunting. Analisa lebih lanjut diperoleh nilai $\mathrm{OR}=2,634$ (95\%CI : 1,392-4,987), sehingga dapat disimpulkan balita yang mendapatkan ASI tidak Eksklusif memiliki kecendrungan 3 kali akan stunting dibanding balita yang mendapatkan ASI Eksklusif.

\section{PEMBAHASAN}

\section{Hubungan Antara Pekerjaan Ibu Dengan Kejadian Stunting Pada Balita 6-59 Bulan Di Kabupaten Bangka Selatan.}

Faktor pekerjaan memepengaruhi pengetahuan, seseorang yang bekerja pengetahuannyaakan lebih luas dari pada seseoarang yang tidak bekerja, karena orang yang bekerja lebih banyakmemeperoleh informasi. Karakteristik ibu perlu juga diperhatikan karena stunting yang sifatnyakronis, artinya muncul sebagai akibat dari keadaan yang berlangsung lama seperti kemiskinan,pola asuh yang tidak tepat karena akibat dari orang tua yang sangat sibuk bekerja, pengetahuanibu yang kurang baik tentang gizi akibat dari rendahnya pendidikan ibu, sering menderitapenyakit secara berulang karena higiene dan sanitasi yang kurang baik. ${ }^{6}$

Hasil penelitian ini membuktikan Adanya hubungan antara pekerjaan ibu dengan kejadian stunting ( $p$ $=0,000$ ), dimana ibu yang tidak bekerja memiliki kecenderungan 5 kali anak akan mengalami stunting dibandingkan dengan ibu yang bekerjanilai $(\mathrm{OR}=5,390)$.

Hasil penelitian ini sejalan dengan penelitian yang dilakukan oleh Yulia Wulansari (2017) yang menyatakan ada hubungan yang bermakna antara pekerjaan ibu dengan resiko kejadian stunting pada balita $(p=0,0001)^{7}$,sejalan dengan penelitian yang dilakukan oleh Novita Siahaan, dkk (2013) yang menyatakan ada hubungan yang bermakna antara pekerjaan ibu dengan kejadian stunting $(\mathrm{p}=0,04)^{8}$ namun bertolak belakang dengan penelitian yang dilakukan oleh Aisyah, dkk (2018 menunjukkan bahwa tidak terdapat hubungan antara pekerjaan ibu dengan kejadian stunting pada anak kelas satu di SDI Taqwiyatul Wathon Daerah Pesisir Kota Semarang $(\mathrm{p}=0,154){ }^{9}$

Peneliti berpendapat profesi ibu bekerja di luar rumah untuk mencari nafkah, baik untuk dirinya sendiri maupun untuk keluarganya itu berbeda-beda. Status pekerjaan ibu sangat menentukan prilaku ibu dalam pemberian nutrisi kepada balita. Ibu yang bekerja berdampak pada rendahnya waktu bersama ibu dengan anak sehingga asupan makanan tidak terkontrol dengan baik dan juga perhatian ibu terhadap anak perkembangan anak menjadi berkurang.

\section{Hubungan Antara Jenis Kelamin Balita Dengan Kejadian Stunting Pada Balita 6-59 Bulan Di Kabupaten Bangka Selatan.}

Studi kohort di Ethiophia menunjukan bayi dengan jenis kelamin laki-laki memiliki risiko dua kali lipat menjadi stunting dibandingkan bayi perempuan pada usia 6 dan 12 bulan. ${ }^{10}$ Anak laki-laki 
berisiko stunting dan underweight dibandingkan anak perempuan. Beberapa penelitian di Sub-Sahara Afrika menunjukan bahwa aak laki-laki prasekolah lebih berisiko stunting dibandingkan dengan rekan anak perempuannya. Dalam hal ini, tidak diketahui alasannya. ${ }^{11}$

Hasil penelitian ini membuktikan tidak ada hubungan antara jenis kelamin balita dengan kejadian stunting $(p=0,874)$, dimana balita berjenis kelamin laki-laki memiliki kecederungan 1 kali akan mengalami stunting dibandingkan dengan balita berjenis kelamin perempuan dengan nilai $(\mathrm{OR}=0,905)$.

Hasil penelitian ini sejalan dengan penelitian yang dilakukan oleh Nojomi, dkk (2004), yang menyatakan bahwa tidak ada hubungan yang signifikan antara jenis kelamin dengan kejadian stunting pada balita. ${ }^{12}$ Namun penelitian ini bertolak belakang dengan penelitian yang dilakukan oleh Yulia Wulansari (2017) yang menyatakan ada hubungan yang bermakna antara jenis kelamin balita dengan resiko kejadian stunting pada balita $(\mathrm{p}=0,0001){ }^{7}$

Peneliti berpendapat bahwa jenis kelamin balita tidak mempengaruhi kejadian stunting. Stuntingdapat terjadi karena berbagai factor, Salah satunya faktor asupan, karena pada fese pertumbuhan dibutuhkan cukup asupan energi, protein dan lemak. Karena pada balita, baik laki-laki maupun perempuan, akan mengalami gangguan pertumbuhan jika asupan energi dan protein berkurang.

\section{Hubungan Antara ASI Eklusif Dengan Kejadian Stunting Pada Balita Usia 6-59 Bulan Di Kabupaten Bangka Selatan.}

Air Susu Ibu (ASI) merupakan makanan terbaik bagi bayi. ASI Eksklusif mampu menurunkan angka kesakitan dan kematian anak. Menurut Peraturan Pemerintah Republik Indonesia Nomor 33 tahun 2012 tentang Pemberian ASI eksklusif, ASI eksklusif adalah ASI yang diberikan kepada bayi sejak dilahirkan selama enam bulan tanpa menambahkan dan atau mengganti dengan makanan atau minuman lain. ${ }^{13}$ ASI Eksklusif adalah bayi hanya diberi ASI saja selama enam bulan tanpa tambahan cairan lain seperti susu formula, jeruk, madu, air teh, dan air putih, serta tanpa tambahan makanan padat seperti pisang, bubur susu, biskuit, bubur nasi dan nasi tim kecuali vitamin, mineral dan obat. ${ }^{14}$ Hasil penelitian ini membuktikan Adanya hubungan antara ASI Eklusif dengan kejadian stunting $(p=$ 0,004) dimana balita yang tidak mendapatkan ASI Eklusif memiliki kecenderungan 3 kali akan mengalami stunting dibanding balita yang mendapatkan ASI Eklusif $(\mathrm{OR}=2,634)$.

Hal ini sejalan dengan penelitian oleh (Hidayah, 2013) yang menemukanan bahwa ada hubungan bermakna antara ASI eksklusif dengan kejadian stunting pada anak balita. ${ }^{15}$ Penelitian ini juga sejalan dengan penelitian yang dilakukan Aridiyah (2015) bahwa kejadian stunting pada anak balita baik yang berada di wilayah pedesaan maupun perkotaan dipengaruhi oleh variabel pemberian ASI eksklusif. ${ }^{16}$ Akan tetapi, hasil penelitian ini tidak sejalan dengan penelitian (Anshori, 2014) yang mendapatkan bahwa ASI Ekslusif bukan merupakan faktor risiko kejadian stunting pada anak balita. ${ }^{17}$ Hasil penelitian ini juga sejalan dengan penelitian yang dilakukan (Ahmad, 2010) Bahwa stunting lebih banyak ditemukan pada anak yang tidak diberi ASI Eklusif di bandingkan anak yang diberi ASI Eklusif. ${ }^{18}$

Peneliti berpendapat bahwa rendahnya pemberian ASI eksklusif menjadi salah satu pemicu terjadinya stunting pada anak balita. ASI eksklusif merupakan factor protektif terhadap kejadian stunting pada balita sehingga pemberian ASI eksklusif dapat menurunkan kejadian stunting.

\section{SIMPULAN}

Berdasarkan hasil penelitian yang telah dilakukan yang berjudul "Hubungan Pekerjaan Ibu, Jenis Kelamin Balita, dan ASI Eklusif Dengan Kejadian Stunting Pada Balita 6-59 Bulan di Kabupaten Bangka Selatan," didapatkan kesimpulan, yaitu: ada hubungan antara pekerjaan ibu dengan kejadian stunting pada balita 6-59 bulan di Kabupaten Bangka Selatan $(p=0,000)$; tidak ada hubungan jenis kelamin balita dengan kejadian stunting pada balita 6-59 bulan di kabupaten bangka selatan ( $p=$ 0,874); dan ada hubungan antara pemberian asi eklusif dengan kejadian stunting pada balita 6-59 bulan di Kabupaten Bangka Selatan $(p=0,004)$. 


\section{SARAN}

Diharapkan kepada peneliti selanjutnya agar dapat mengembangkan variabel-variabel penelitian seperti BBLR, Pendidikan Ibu, dan Pola Asuh.

\section{UCAPAN TERIMA KASIH}

Terimakasih peneliti ucapkan kepada segala pihak yang telah mendukung penyelesaian penelitian ini, yaitu Kemenristekdikti, yang telah memberikan dukungan berupa dana hibah penelitian dosen. STIKES Citra Delima Bangka Belitung, yang telah memberikan wewenang serta bantuan fasilitas perpustakaan dalam mendukung refrensi-refrensi yang digunakan dalam penelitian. Dinas Kesehatan Provinsi Bangka Belitung, yang telah menyambut baik penelitian yang kami lakukan, terimakasih atas bantuan-bantuan data. Masyarakat Kabupaten Bangka Selatan yang telah bersedia untuk menjadi responden penelitian.

\section{DAFTAR PUSTAKA}

1. Riskesdas. Laporan Nasional Riset Kesehatan Dasar (Riskesdas Tahun 2013). Jakarta : Badan Penelitian dan Pengembangan Kesehatan Departemen ; 2013

2. Kementrian Kesehatan Republik Indonesia. Pemantauan Status Gizi. Jakarta:Kementrian Kesehatan Republik Indonesia; 2016

3. Dinas Kesehatan Provinsi Kepulauan Bangka Belitung. Profil Dinas Kesehatan Provinsi Kepulauan Bangka Belitung. Pangkalpinang:Dinas Kesehatan Provinsi Kepulauan Bangka Belitung; 2017

4. Sari M, Pee Sd, Bloem MW, Sun K, ThormeLyman AL, MoenchPfanner R, et al. Higher Household expenditure on animal-source and nongrain foods lowers the risk of stunting among children 0-59 months old in Indonesia : Implications of Rising Food Prices. The Journal of Nutrition ; 2010

5. UNICEF.Data Balita Stunting. Indonesia ; 2013

6. Khusniyah.In A. Susanto Dwi. 2015. Hubungan Status Pekerjaan Ibu DanPengetahuan Ibu Mengenai Mpasi Terhadap Status Gizi Batita Di Posyandu Sukowidodo 1,2, Dan 3 Desa Ngargorejo, Boyolali. Surakarta: Program Studi Diii Gizi Fakultas IlmuKesehatan Universitas Muhammadiyah Surakarta; 2011

7. Wulansari, Yulia.Faktor-faktor Yang Berhubungan Dengan Risiko Kejadian Stunting PadaBalita Usia 6-59 Bulan di Wilayah Kerja Puskesmas Gerunggang Kota Pangkalpinang Tahun 2017.Skripsi Strata Satu, STIKES Citra Delima Bangka Belitung, Pangkalpinang ; 2017

8. Siahan, Novita. Faktor-faktor penyebab Stunting. In Wulansari, Yulia. 2017. Faktor-faktorYang Berhubungan Dengan Risiko Kejadian Stunting Pada Balita Usia 6-59 Bulan di Wilayah KerjaPuskesmas Gerunggang Kota Pangkalpinang Tahun 2017. Skripsi Strata Satu, STIKES Citra DelimaBangka Belitung, Pangkalpinang ; 2013

9. Aisyah, dkk. Faktor-Faktor Yang Berhubungan Dengan Stunting Pada Anak Kelas Satu Di SdiTaqwiyatul Wathon, Daerah Pesisir Kota Semarang. Diakses 1 November 2019, darihttps://ejournal3.undip.ac.id/index.php/jkm/article/view/22972/21009; 2018

10. Medhin. Balita Stunting. In A. Paramitha. 2012. Faktor-faktor yang berhubungan dengankejadian stunting pada balita 25-60 bulan di Kelurahan Kalibiru Depok Tahun 2012.Diakses1November2019, darihttp://libui.ac.id/file?file=digital/20320460-

SParamitha\%20Anisa.pdf; 2010

11. Lesiapeto, Balita Stunting. In A. Paramitha. 2012. Faktor-faktor yang berhubungan dengankejadian stunting pada balita 25-60 bulan di Kelurahan Kalibiru Depok Tahun 2012. Diakses 1November 2019, dari http://lib.ui.ac.id/file?file=digital/20320460-SParamitha\%20Anisa.pdf ; 2010

12. Nojomi, dkk.Kejadian Stunting Pada Balita. In . Paramitha. 2012. Faktor-faktor yangberhubungan dengan kejadian stunting pada balita 25-60 bulan di Kelurahan Kalibiru Depok Tahun2012. Diakses 1 November 2019, dari http://lib.ui.ac.id/file?file=digital/20320460SParamitha\%20Anisa.pdf. 2004 
13. Septikasari, M.Status gizi anak dan faktor yang mempengaruhi. Yogyakarta: UNY Press ; 2018

14. Septikasari, M.Asi Eklusif. In Debi Akbaria. Faktor - Faktor Yang Berhubungan DenganKejadian Stunting Pada Balita Usia 0-5 Tahun Di Desa Jada Bahrin Wilayah Kerja Puskesmas BaturusaTahun 2018. Skripsi Strata Satu. STIKES Citra Delima Bangka Belitung, Pangkalpinang ; 2011

15. Hidayah F. ASI Eksklusif sebagai Faktor Risiko Kejadian Stunting Pada Anak Usia 6-24 Bulan diKota Yogyakarta. Yogyakarta: Universitas Gajah Mada; 2013.

16. Aridiyah, dkk.Faktor-faktor yang Mempengaruhi Kejadian Stunting pada AnakBalita di Wilayah Pedesaan dan Perkotaan. Skripsi Strata Satu, Universitas Jember, Jember ; 2015

17. Anshori, H.Faktor Risiko Kejadian Stunting Pada Anak Balita Usia 12-24 Bulan DiKecamatan Semarang Timur. Skripsi, Semarang: Program Studi Ilmu Gizi Fakultas KedokteranUniversitas Diponegoro. Diakses April 2014, dari http://eprints.undip.ac.id ; 2013

18. Ahmad.ASI Eksklusif Anemia dan Stunting pada Anak Baduta (6-24 bulan) Di KecamatanDarul Imarah Kabupaten Aceh Besar. Jurnal Gizi Poltekkes Kemenkes Aceh : Aceh ; 2010 